\title{
Hepatic arterial embolization in patients with neuroendocrine tumors
}

\author{
Michela Del Prete ${ }^{1 \dagger}$, Francesco Fiore ${ }^{2 \dagger}{ }^{4}$, Roberta Modica ${ }^{1}$, Vincenzo Marotta ${ }^{1}$, Francesca Marciello ${ }^{1}$, Valeria Ramundo ${ }^{1}$, \\ Antonella Di Sarno ${ }^{3}$, Annachiara Carratù ', Chiara de Luca di Roseto', Salvatore Tafuto ${ }^{4}$, Fabiana Tatangelo ${ }^{5}$, \\ Robero Baldelli ${ }^{6}$, Annamaria Colao ${ }^{1}$, Antongiulio Faggiano ${ }^{1^{*}}$ on the behalf of the Multidisciplinary Group for \\ NeuroEndocrine Tumors of Naples
}

\begin{abstract}
Liver metastases occur in 46-93\% of patients with neuroendocrine neoplasms (NENs). Presence and extension of liver metastases are considered important prognostic factors, as they may significantly impair the patient's quality of life, because of either tumor bulk or hormonal hypersecretion. Therapies for NEN liver metastases include surgical resection, liver transplantation, chemotherapy and biotherapy. Surgery is the gold standard for curative therapy, but in most of NEN patients with liver metastases, when surgery can not be applied, minimally invasive therapeutic approaches are adopted. They include trans-arterial embolization (TAE), trans-arterial chemoembolization (TACE), radiofrequency thermal ablation and new emerging techniques.

TAE is based on selective infusion of particles in the branch of the hepatic artery supplying the tumor lesions. The goal of TAE is to occlude tumor blood vessels resulting in ischemia and necrosis. Many reports have shown that TAE can reduce tumor size and hormone output, resulting in palliation of symptoms without the use of cytotoxic drugs, resulting in better tolerability. This review will focus on TAE performance and safety in NEN patients with liver metastases.
\end{abstract}

Keywords: Embolization, Chemoembolization, Liver metastases, Neuroendocrine tumor

\section{Introduction}

Neuroendocrine neoplasms (NEN)s represent a heterogeneous group of neoplasms with distinct morphological and biological manifestations. According to the 2010 WHO classification, NENs are divided into: well differentiated neuroendocrine neoplasm (NEN) G1 (mitotic count $<2$ per 10 high power fields (HPF) and/or $\leq 2 \%$ Ki67 index), NEN G2 (mitotic count 2-20 per $10 \mathrm{HPF}$ and/or 3-20\% Ki67 index), and poorly differentiated high grade malignant neoplasm (NEC) G3 (mitotic count $>20$ per $10116 \mathrm{HPF}$ and/or $>20 \%$ Ki67 index) [1]. Most common sites of origin are the gastrointestinal tract and the bronchopulmonary system. With a global incidence of approximately 5-7 cases per 100,000 per yr,

\footnotetext{
* Correspondence: afaggian@unina.it

${ }^{\dagger}$ Equal contributors

1 Divisione di Endocrinologia, Dipartimento di Medicina Clinica e Chirurgia, Università di Napoli Federico II, Naples, Italy

Full list of author information is available at the end of the article
}

gastroenteropancreatic NEN represents the second most frequent digestive cancer [2,3]. Metastatic involvement of the liver typically develops in about $46-93 \%$ of NEN patients [4,5]. In $12.9 \%$ of these patients, metastases are already detectable at the time of initial tumor diagnosis and $5-10 \%$ of them present with metastases and primary of unknown origin. Up to $75 \%$ of patients with small bowel NEN and $30-85 \%$ of those with pancreatic NEN present with liver metastases either at initial evaluation or during the course of their disease [6-8]. Presence and extension of liver metastases are considered important prognostic factors for NENs as they may significantly impair the patient's quality of life because of either tumor bulk or hormonal hypersecretion. Liver metastases can result in a gradual replacement of liver parenchyma resulting in a progressive deficit of function until death, thus decreasing long term survival. Treatment of liver metastases can be curative or palliative. An effective treatment has to result in control of tumor growth and systemic hormonal effect, improvement of quality of life 
and increase of survival [9]. The treatment of liver metastases should take into account the natural history of the disease, the degree of liver involvement and the severity of related symptoms. The first line treatment of liver metastases is surgery and it can be curative for NEN G1/G2 or palliative. Complete resection (R0/R1) is associated with better long-term survival and quality of life. Resection of NEC G3 is not recommended, but may be considered in individual cases with isolated resecable metastases. Debulking resections (reduction of tumor mass $>90 \%$, resection of metastases and lymphnodes) can exceptionally be justified in palliative situations and incompleted debulking surgery (R2) has limited indication especially in functioning tumors [10]. However, only $10-20 \%$ of patients are eligible for either palliative or curative surgical resection. Liver transplantation is a potentially curative approach but limited to extremely selected patients and in experienced centers; moreover risk of recurrence persists in the transplantated liver [11].

For patients with multiple site metastases, systemic therapies are required to control tumor growth and clinical symptoms. They include chemotherapy (with streptozotocin or other agents), biotherapy with somatostatin analogs and/or alpha interferon and therapy with new agents targeting specific molecular pathways [12-17]. In most of NEN patients with liver metastases, minimally invasive, loco-regional approaches are adopted in place of surgery. They include trans-arterial embolization (TAE), trans-arterial chemoembolization (TACE), radiofrequency thermal ablation. Newly developed locoregional ablative procedures are under evaluation. TAE is based on selective infusion of particles in the branch (segmental or subsegmental) of the hepatic artery supplying the tumor lesions. The goal of TAE is to occlude tumor blood vessels resulting in ischemia and necrosis. TACE differs from TAE for the administration of a chemotherapeutic agent (anthracyclines such as Doxorubicin or Epirobicin) mixed with Lipiodol (fat-soluble contrast-medium with high concentration of Iodine; Lipiodol R), into the hepatic artery followed by the administration of embolizing agents $(75-150 \mu \mathrm{m})$. In TAE treatment, Lipiodol administration (50\%) is followed by the administration of embolizing agents (75-150 $\mu \mathrm{m})$ without the administration of chemotherapeutic agents. Eligible patients for these procedures include NEN patients in metastatic phase, with predominant liver disease, which is judjed not resectable by surgery $[18,19]$. Although both techniques have been widely adopted, it remains debatable if the addition of cytotoxic drugs to embolization material increases the effectiveness of bland embolization alone, particularly when performed selectively $[20,21]$. This review will focus on TAE in NEN patients with liver metastases.

\section{Clinical, biochemical, instrumental characterization of NEN patients before TAE}

Clinical work-up has to establish if the tumor is associated with a functioning endocrine syndrome which can result also in life-threatening conditions. Carcinoid syndrome is the most frequent functioning endocrine syndrome predominantly associated with the presence of liver metastases (60\%). Regardless from endocrine symptoms, tumor mass-related symptoms need to be carefully evaluated, highlighting in particular the patient performance status, hepatic function and degree of liver involvement by the tumor, as liver metastases are often multilocular and bilateral [22]. Plasma chromogranin A ( $\mathrm{CgA})$ should be measured in all cases in order to have a potential sensitive marker, helpful for tumor monitoring and follow-up. However falsepositive $\mathrm{CgA}$ false positive need to be carefully excluded [23,24]. The $24 \mathrm{~h}$ urinary 5 -hydroxyindolacetic acid (5-HIAA) is an additional sensitive marker in NENs with carcinoid syndrome [25]. Other helpful NEN markers related to the specific syndrome are insulin, gastrin, glucagons or vasoactive intestinal polypeptide, to be evaluated according to the clinical picture [26,27].

Contrast-enhanced abdominal ultrasound and multidetector-row computed tomography (CT) are the standard initial imaging procedures. Advanced CT protocols and fusioning CT - positron emission tomography (PET) showed a sensitivity of $94-100 \%[28,29]$. As an alternative to $\mathrm{CT}$, magnetic resonance imaging (MRI), using gadolinium as liver-specific contrast agents, is recommended for routine staging, assessment of disease progression and monitoring of the therapy [30]. Functional imaging is mainly based on the [111-In-diethylene-triamine-pentaacetic-acid (DTPA)-D-Phe1]-octreotide (Octreoscan). Nowadays this technique has been replaced in several centers with ${ }^{68} \mathrm{Ga}$-radilabelled PET [31-33]. The diagnostic workup of liver metastases should encompass tissue acquisition for histopathological and immunohistochemistry examination, since staging of NEN depends on markers of proliferation, such as Ki-67 and mitotic index and evaluation of vascular and neural invasiveness. Tumor staging predicts the prognosis and tailors the therapeutic strategy, particularly in patients who are not candidates for complete resection [34].

\section{Embolization procedures}

Hepatic arterial embolization using a percutaneous Seldinger technique under radiological control was developed for metastatic endocrine tumors in the early 1970s. Indications for TAE generally include unresectability with symptoms related to tumor bulk, excessive hormone production, and rapid progression of liver disease. TAE has been shown to improve biophysical markers, palliate symptoms and reduce tumor burden 
at the radiological evaluation [20,35]. Neuroendocrine liver metastase are higly vascular and receive their blood supply from the hepatic artery $(>90 \%)$, while normal liver receives $75-80 \%$ of its blood supply from the portal vein. TAE aims to create tumor ischemia embolizing the tumor feeding hepatic arterial branches [36]. Tumor ischemia has already been demonstrated useful in primary hepatocellular carcinoma, and now it finds indication for treatment of neuroendocrine liver metastases. In TACE procedure, tumor tissue ischemia

Table 1 Tumour response and survival rate in patients treated with Transarterial Embolization (TAE)

\begin{tabular}{|c|c|c|c|c|}
\hline Paper & $\begin{array}{l}\text { Number and type } \\
\text { of NEN }\end{array}$ & $\begin{array}{l}\text { Number of } \\
\text { TAEs }\end{array}$ & TR & OS \\
\hline \multirow[t]{2}{*}{ Loewe et al. 2003 [7] } & 23 carcinoids & 75 TAE & 4 (18\%) CR, 12 (55\%) PR, 6 (27\%) PD & 69 months \\
\hline & & & (22 pts evaluable) & \\
\hline \multirow[t]{4}{*}{ Gupta et al. 2003 [18] } & 69 carcinoids & Carcinoids: & $\begin{array}{c}\text { Carcinoids: } 46 \text { (67\%) PR, } 6 \text { (8.5\%) MR, } \\
11(16 \%) \text { SD, } 6 \text { (8.5\%) PD }\end{array}$ & 18 months \\
\hline & 54 PNENs & $42 \mathrm{TAE} / 27 \mathrm{TACE}$ & PNEN: 19 (35\%) PR, 1 (2\%) MR, & \\
\hline & & PNENs: & & \\
\hline & & $32 \mathrm{TAE} / 22 \mathrm{TACE}$ & & \\
\hline \multirow[t]{2}{*}{ Carrasco et al. 1986 [32] } & 25 carcinoids & 25 TAE & $20(87 \%) C R, 1(5 \%) P D$ & 11 months \\
\hline & (23 evaluable) & & & \\
\hline \multirow{3}{*}{$\begin{array}{l}\text { Strosberg et al. } \\
2006[36]\end{array}$} & 59 carcinoids & $161 \mathrm{TAE}$ & 23 pts evaluable: 11 (48\%) PR, & 36 months \\
\hline & 20 PNENs & & & \\
\hline & 5 unspecified NENs & & & \\
\hline Hanssen et al. 1989 [39] & $\begin{array}{l}19 \text { carcinoids } \\
\text { (7 evaluable) }\end{array}$ & $7 \mathrm{TAE}$ & $7(100 \%) P R$ & 12 months \\
\hline $\begin{array}{l}\text { Wangberg et al. } \\
1996[40]\end{array}$ & 64 carcinoids & $40 \mathrm{TAE}$ & --- & 60 months \\
\hline \multirow[t]{2}{*}{ Eriksson et al. 1998 [41] } & 29 carcinoids & $55 \mathrm{TAE}$ & $\begin{array}{c}\text { Carcinoids: } 18 \text { (62\%) CR, } 9 \text { (31\%) SD, } \\
2 \text { (7\%) PD }\end{array}$ & 80 months (carcinoids) \\
\hline & 12 PNENs & & $\begin{array}{c}\text { PNEN: } 6(67 \%) \text { CR } \\
1 \text { (11\%) SD, } 2 \text { (22\%) PD }\end{array}$ & 20 months (PNEN) \\
\hline \multirow[t]{2}{*}{ Brown et al. 1999 [42] } & 21 carcinoids & 63 TAE & --- & 60 months \\
\hline & 14 PNENS & & & \\
\hline \multirow{2}{*}{$\begin{array}{l}\text { Chamberlain et al. } \\
2000[43]\end{array}$} & 41 carcinoids & 59 TAE & 33 pts evaluable: 19 (58\%) SD & NR \\
\hline & 44 PNENs & & & \\
\hline \multirow{2}{*}{$\begin{array}{l}\text { Ruutiainen et al. } \\
2007 \text { [44] }\end{array}$} & 67 unspecified NENs & $23 \mathrm{TAE} / 44 \mathrm{TACE}$ & $(100 \%) C R$ & 36 months \\
\hline & & (219 procedures) & (35\%) CR & \\
\hline \multirow[t]{3}{*}{ Ho et al. 2007 [45] } & 31 carcinoids & $7 \mathrm{TAE} / 86 \mathrm{TACE}$ & 33 pts evaluable: & 48 months \\
\hline & 15 PNEN & & $\begin{array}{c}\text { Carcinoids: } 5 \text { (23\%) PR, } 5 \text { (23\%) MR, } \\
7 \text { (31\%) SD, } 5 \text { (23\%) PD** }\end{array}$ & \\
\hline & & & $\begin{array}{c}\text { PNEN: } 2 \text { (18\%) PR, } 3 \text { (27\%) MR, } \\
5 \text { (46\%) SD, } 1 \text { (9\%) PD* }\end{array}$ & \\
\hline \multirow[t]{2}{*}{ Kamat et al. 2008 [46] } & 60 unspecified NENs & $33 \mathrm{TAE} / 27 \mathrm{TACE}$ & $\begin{array}{l}12(25 \%) \mathrm{PR}, 6(12 \%) \mathrm{MR} \\
22(46 \%) \mathrm{SD}, 8 \text { (17\%) PD* }\end{array}$ & 9.3 months \\
\hline & & (123 procedures) & 48 pts evaluable & \\
\hline Pitt et al. 2008 [47] & 100 unspecified NENs & 106 TAE/123 TACE & -- & 32.4 months \\
\hline Sward et al. 2009 [48] & 107 carcinoids & 213 TAE & -- & 56 months \\
\hline \multirow[t]{3}{*}{ Fiore et al. 2014 [50] } & 12 PNENs & $38 \mathrm{TAE} / 37 \mathrm{TACE}$ & 17 pts evaluable: & 60 months \\
\hline & 16 NENs ileum & & 12 (70\%) CR, 5 (30\%) PR & \\
\hline & 2 NENs colon & & & \\
\hline
\end{tabular}


Table 2 Symptomatic and biochemical response in patients treated with TAE

\begin{tabular}{|c|c|c|c|c|c|}
\hline Paper & $\begin{array}{l}\text { Number and } \\
\text { type of NEN }\end{array}$ & Number of TAEs & BR & $\begin{array}{l}\text { SR (endocrine } \\
\text { symptoms) }\end{array}$ & $\begin{array}{l}\text { SR (aspecific } \\
\text { symptoms) }\end{array}$ \\
\hline \multirow{4}{*}{$\begin{array}{l}\text { Loewe et al. } \\
2003 \text { [7] }\end{array}$} & \multirow{4}{*}{$\begin{array}{l}23 \text { small-bowel } \\
\text { NENs }\end{array}$} & \multirow[t]{4}{*}{75} & \multirow{4}{*}{$\begin{array}{c}13 \text { pts evaluable: } 8 \text { (61\%) PR, } \\
5(39 \%) \text { MR }\end{array}$} & 9 pts evaluable: & \multirow[t]{4}{*}{$-\cdots$} \\
\hline & & & & $\begin{array}{c}\text { Abdominal pain } 5(56 \%) \\
\text { PR }\end{array}$ & \\
\hline & & & & Diarrhea 2 (22\%) CR & \\
\hline & & & & Flushing 2 (22\%) CR & \\
\hline \multirow{4}{*}{$\begin{array}{l}\text { Gupta et al. } \\
2003[18]\end{array}$} & \multirow[t]{2}{*}{69 carcinoids } & Carcinoids: & \multirow[t]{4}{*}{--} & \multirow[t]{4}{*}{-} & \multirow[t]{4}{*}{--} \\
\hline & & $42 \mathrm{TAE} / 27 \mathrm{TACE}$ & & & \\
\hline & \multirow[t]{2}{*}{54 PNENs } & PNENs: & & & \\
\hline & & $32 \mathrm{TAE} / 22 \mathrm{TACE}$ & & & \\
\hline $\begin{array}{l}\text { Carrasco et al. } \\
1986[32]\end{array}$ & 25 carcinoids & 25 & $18(72 \%) C R$ & --- & $20(87 \%) C R$ \\
\hline \multirow[t]{4}{*}{$\begin{array}{l}\text { Strosberg et al. } \\
2006[36]\end{array}$} & 59 carcinoids & 161 & 35 pts evaluable: & $\begin{array}{c}\text { Flushing and/or } \\
\text { diarrhea } 21(48 \%) C R\end{array}$ & $9(20 \%) C R$ \\
\hline & 20 PNENS & & $28(80 \%) C R$ & $\begin{array}{l}\text { Abdominal pain } 11 \\
\text { (25\%) CR }\end{array}$ & (44 pts evaluable) \\
\hline & \multirow[t]{2}{*}{5 unspecified NENs } & & $4(11 \%) M R$ & Hypoglicemia 3 (7\%) CR & \\
\hline & & & $3(9 \%)$ no response & (44 pts evaluable) & \\
\hline $\begin{array}{l}\text { Hanssen et al. } \\
1989 \text { [39] }\end{array}$ & $\begin{array}{l}19 \text { carcinoids (7 pts } \\
\text { evaluable) }\end{array}$ & 7 & 7 (100\%) PR & $\begin{array}{l}\text { Diarrhea and/or } \\
\text { flushing: } 7 \text { (100\%) CR }\end{array}$ & -- \\
\hline \multirow{2}{*}{$\begin{array}{l}\text { Wangberg et al. } \\
1996[40]\end{array}$} & 64 carcinoids & \multirow[t]{2}{*}{40} & \multirow[t]{2}{*}{40 (100\%) PR } & \multirow[t]{2}{*}{--} & \multirow[t]{2}{*}{40 (100\%) PR } \\
\hline & (40 pts evaluable) & & & & \\
\hline \multirow[t]{2}{*}{$\begin{array}{l}\text { Eriksson et al. } \\
1998[41]\end{array}$} & 29 carcinoids & \multirow[t]{2}{*}{55} & $\begin{array}{c}\text { Carcinoids: } 12(41 \%) \text { PR, } 8 \text { (28\%) MR, } \\
9 \text { (31\%) no response }\end{array}$ & \multirow[t]{2}{*}{---} & $\begin{array}{l}11 \text { carcinoid } \\
(38 \%) C R\end{array}$ \\
\hline & 12 PNENs & & $\begin{array}{c}\text { PNEN: } 6(50 \%) \text { PR, } 2 \text { (16\%) MR, } \\
4(34 \%) \text { no response }\end{array}$ & & 6 PNEN (50\%) CR \\
\hline \multirow{2}{*}{$\begin{array}{c}\text { Brown et al. } \\
1999[42]\end{array}$} & 21 carcinoids & 63 & \multirow[t]{2}{*}{--} & \multirow[t]{2}{*}{--} & $46(96 \%) P R$ \\
\hline & 14 PNENS & (48 evaluable) & & & $\begin{array}{l}\text { (48 TAE } \\
\text { evaluable) }\end{array}$ \\
\hline \multirow{3}{*}{$\begin{array}{c}\text { Chamberlain et al. } \\
2000[43]\end{array}$} & 41 carcinoids & \multirow[t]{3}{*}{59} & \multirow[t]{3}{*}{--} & 33 pts evaluable & \multirow[t]{3}{*}{31 (94\%) PR } \\
\hline & $\begin{array}{l}26 \text { non functional } \\
\text { PNENs }\end{array}$ & & & $\begin{array}{l}\text { Hormonal and/or pain } \\
\text { symptoms }\end{array}$ & \\
\hline & $\begin{array}{l}18 \text { functional } \\
\text { PNENs }\end{array}$ & & & $31(94 \%)$ PR & \\
\hline $\begin{array}{l}\text { Ruutiainen et al. } \\
2007 \text { [44] }\end{array}$ & $\begin{array}{l}67 \text { unspecified } \\
\text { NENs }\end{array}$ & $\begin{array}{l}23 \text { TAE/44 TACE (219 } \\
\text { procedures) }\end{array}$ & -- & -- & -- \\
\hline \multirow{2}{*}{$\begin{array}{l}\text { Ho et al. } \\
2007[45]\end{array}$} & 46 NENs & 7TAE/86 TACE & -- & -- & 27 pts evaluable \\
\hline & $\begin{array}{l}\text { (31 carcinoids; } 15 \\
\text { PNEN) }\end{array}$ & & & & $21(78 \%)$ PR \\
\hline Kamat et al. & 60 unspecified & $33 \mathrm{TAE} / 27 \mathrm{TACE}$ & -- & -- & 20 pts evaluable \\
\hline $8[46$ & & (123 procedures) & & & $13(65 \%)$ PR \\
\hline $\begin{array}{l}\text { Pitt et al. } \\
2008 \text { [47] }\end{array}$ & $\begin{array}{l}100 \text { unspecified } \\
\text { NENs }\end{array}$ & 106TAE/123TACE & --- & -- & $\begin{array}{l}35 \text { pts evaluable: } \\
29 \text { TAE (83\%) PR }\end{array}$ \\
\hline & & & & & $\begin{array}{l}35 \text { pts evaluable: } \\
32 \text { TACE (86\%) PR }\end{array}$ \\
\hline Sward et al. & 107 carcinoids & 213 & 37 pts evaluable: & Diarrhea and/or flushing & $76(71 \%)$ \\
\hline 2009 [48] & & & CgA: 19 (51\%) CR & 年 & \\
\hline & & & 54 pts evaluable: & & \\
\hline & & & 5HIAA: 26 (48\%) CR & & \\
\hline
\end{tabular}


Table 2 Symptomatic and biochemical response in patients treated with TAE (Continued)

\begin{tabular}{|c|c|c|c|c|c|}
\hline \multirow{3}{*}{$\begin{array}{l}\text { Fiore et al. } \\
22014 \text { [50] }\end{array}$} & 12 PNENs & 38 TAE/37 TACE & -- & -- & 19 pts evaluable \\
\hline & 16 NENs ileum & & & & (64\%) $\mathrm{PR}^{*}$ \\
\hline & 2 NENs colon & & & & \\
\hline
\end{tabular}

Legend = PNEN: NEN pancreas, BR: biochemical response, SR: symptomatic response, PR: partial response, CR: complete response, MR: minor response. ${ }^{*}$ Cumulative results.

is caused by both the chemotherapy activity and arterial embolization.

Different protocols have been used in TAE and embolizing agents are lipiodol, gel foam particles, polyvinyl alcohol (PVA) particles or microspheres [37]. Eligibility requirements included intact liver and renal function (bilirubin $<2 \mathrm{mg} / \mathrm{dL}$, serum creatinine level $<2 \mathrm{mg} / \mathrm{dL}$ ). Absolute contraindications were main portal vein occlusion and poor liver function. Other contraindications are: bilirubin greater than $2 \mathrm{mg} / \mathrm{dL}$, hepatic tumor burden greater than $75 \%$, specific contraindications to angiography such as allergy o contrast medium, fever and/or septic state, renal insufficiency, peripheral vascular disease, coagulopathies [38]. All patients were admitted to the hospital prior to the procedure and started intravenous hydration. Prior to embolization, a celiac angiogram was performed to identify the hepatic vasculature and ensure patency of the portal vein. Superior mesenteric artery angiogram was performed if needed to evaluate for accessory or replaced hepatic arteries supplying the liver. Embolization was performed until the selected vessel demonstrates complete or near complete stasis of flow. Usually the liver lobe with the bulkiest disease was embolized first. After embolization, patients were monitored in the hospital and discharged only after their liver enzymes had peaked. All patients were prophylactically administered antibiotics for one week in order to prevent abscess formation. Intravenous narcotics were typically administered for pain control. In case of recurrence or progression, TAE procedure can be performed several times [39]. When proximal embolization of tumor-feeding arteries in hepatic metastases was performed major effectiveness is remarked. Individual embolizations were spaced approximately 4 weeks apart and the majority of patients completed their embolizations in 2 or 3 times $[9,40,41]$.

\section{Efficacy}

Many reviews have been published on loco-regional ablative treatments of liver metastases of NENs. Several studies have been reported on TACE, while only few studies on TAE. This review focuses on TAE performance and safety in patients with liver metastases of NENs. It has to be highlighted that many authors did not report data on clinical response to TAE or reported these data as indirect consequence of decrease of tumour markers.
As a whole, 896 patients with NEN and liver metastases have been treated for a total of 979 TAE procedures. Median survival rates ranged from 10 to 80 months [9,21,35,39,42-52], but in the most of studies it was between 35 and 60 months (Table 1). Survival was reported to be correlated to objective tumor response. Progression free survival ranged from 0 to 60 months. Objective tumour response, including partial and complete response, was 50\% as average (range, 2-100\%). If we consider both tumour response and stabilization of tumor growth, the rate of patients who received a benefit from TAE was about $40 \%$ [9,21,35,39,42-52] (Table 1). Clinical response was about $56 \%$ (range, $9-100 \%$ ). As far as biochemical response is concerned, TAE was reported to be effective in reducing biochemical markers in $>50 \%$ of patients with NEN. In NEN patients with carcinoid syndrome, major decreases in 5-HIAA levels ( $>50 \%$ decrease as compared to baseline) occured in a range of $11-100 \%$ [9,35,39,42-44,51,53-57] (Table 2).

The first study reporting on TAE treatment in patients with liver metastases from NEN was published by Carrasco et al. [35]. A response to TAE was observed in 95\% of patients with malignat liver metastases from carcinoids, with a median response duration of 11 months. Tumour response was subsequently confirmed in all studies performed on TAE and the rate of patients responsive to treatment (objective response plus stability) was always about or more than $80 \%$ and the median reponse duration was about 36 months [9,21,39,47-49,52] (Table 1).

In the Carrasco study, a symptomatic response occurred in $87 \%$ of patients and correlated with size decrease of liver lesions. In the Fiore study a symptomatic response occurred in $64 \%$ of patients who had an uncontrolled endocrine syndrome [52]. Furthermore, a decrease in urine 5-HIAA concentrations of about $41 \%$ as average has been reported [35]. A similar o greater effect on 5-HIAA was confirmed in subsequent studies $[9,35,39,42,43,51,52]$ (Table 2). When combined with somatostatin analogs or interferon therapy, TAE was found to be still more effective in reducing 5-HIAA and controlling carcinoid syndrome [42,43] (Table 2). The biochemical response to repeated TAE cycles was similar to that observed after the first cycle. Finally, the biochemical response was also found to be correlated with survival [51] (Table 2).

Some studies reported a comparison between carcinoid tumors (according to old classifications of NEN) and 
Table 3 Safety of TAE

\begin{tabular}{|c|c|c|c|c|}
\hline Paper & $\begin{array}{l}\text { Number and } \\
\text { type of NEN }\end{array}$ & Number of TAE & Complications & Death \\
\hline \multirow[t]{2}{*}{ Loewe et al. 2003 [7] } & 23 small-bowel NENs & 75 & Decreased body weight 1 (1\%) & $2(8 \%)$ \\
\hline & & & Leg pain $1(1 \%)$ & \\
\hline \multirow[t]{4}{*}{ Gupta et al. 2003 [18] } & 69 carcinoids & Carcinoids: & Serious adverse events 19 (15\%)* & $1(1 \%)$ \\
\hline & 54 PNENS & $42 \mathrm{TAE} / 27 \mathrm{TACE}$ & & \\
\hline & & PNENs: & & \\
\hline & & $32 \mathrm{TAE} / 22 \mathrm{TACE}$ & & \\
\hline \multirow[t]{2}{*}{ Carrasco et al. 1986 [32] } & 25 carcinoids & 25 & -- & $2(8 \%)$ \\
\hline & (23 evaluable) & & & \\
\hline \multirow[t]{3}{*}{ Strosberg et al. 2006 [36] } & 59 carcinoids & 161 & -- & $2(2 \%)$ \\
\hline & 20 PNENS & & & \\
\hline & 5 unspecified NENs & & & \\
\hline \multirow[t]{2}{*}{ Hanssen et al. 1989 [39] } & 19 carcinoids & 7 & -- & -- \\
\hline & (7 evaluable) & & & \\
\hline Wangberg et al. 1996 [40] & 64 carcinoids & 40 & -- & $\begin{array}{l}\text { Increased risk of } \\
\text { cardiovascular deaths } \\
\text { (not specified) }\end{array}$ \\
\hline \multirow[t]{2}{*}{ Eriksson et al. 1998 [41] } & 29 carcinoids & 55 & Unspecified severe complications 6 (10\%) & $13(31 \%)$ \\
\hline & 12 PNENs & & & \\
\hline \multirow[t]{2}{*}{ Brown et al. 1999 [42] } & 21 carcinoids & 63 & Unspecified severe complications 11 (17\%) & $4(6 \%)$ \\
\hline & 14 PNENS & & & \\
\hline \multirow[t]{3}{*}{ Chamberlain et al. 2000 [43] } & 41 carcinoids & 59 & -- & $4(6 \%)$ \\
\hline & 26 non functional PNENs & & & \\
\hline & 18 functional PNENs & & & \\
\hline \multirow[t]{2}{*}{ Ruutiainen et al. 2007 [44] } & 67 unspecified NENs & $23 \mathrm{TAE} / 44 \mathrm{TACE}$ & Unspecified toxicity $34(50 \%)^{*}$ & (1) $1.4 \% *$ \\
\hline & & (219 procedures) & & \\
\hline \multirow[t]{2}{*}{ Ho et al. 2007 [45] } & 46 NENs & $7 \mathrm{TAE} / 86 \mathrm{TACE}$ & Unspecified complications $9(10 \%)^{*}$ & $4(4.3 \%)$ \\
\hline & (31 carcinoids; 15 PNEN) & & & \\
\hline \multirow[t]{2}{*}{ Kamat et al. 2008 [46] } & 60 unspecified NENs & $33 \mathrm{TAE} / 27 \mathrm{TACE}$ & Unspecified complications $21(35 \%)^{*}$ & $12(20 \%)$ \\
\hline & & (123 procedures) & & \\
\hline Pitt et al. 2008 [47] & 100 unspecified NENs & 106TAE/123TACE & $\begin{array}{l}\text { Liver abscesses, ileus, groin hematoma, } \\
\text { hypotension } 7 \text { (13\%) TAE hematoma, } \\
\text { acute renal failure, and a biloma } 3 \text { (6\%) TACE }\end{array}$ & $3(3 \%)^{*}$ \\
\hline \multirow[t]{3}{*}{ Sward et al. 2009 [48] } & 107 carcinoids & 213 & Liver abscess 4 (4\%) & $2(2 \%)$ \\
\hline & & & Mild pancreatitis 1 (1\%) & \\
\hline & & & $\begin{array}{c}\text { Accidental occlusions of the common } \\
\text { hepatic artery } 2(2 \%)\end{array}$ & \\
\hline \multirow[t]{3}{*}{ Fiore et al. 2014 [50] } & 12 PNENs & $38 \mathrm{TAE} / 37 \mathrm{TACE}$ & Post-embolization syndrome 6 (40\%) TAE & $0 \%$ \\
\hline & 16 NENs ileum & & Post-embolization syndrome 8 (60\%) TACE & \\
\hline & 2 NENs colon & & & \\
\hline
\end{tabular}

*Cumulative results.

pancreatic NENs. Eriksson et al. reported a median survival of 80 months in patients with midgut carcinoid tumors and 20 months in those with pancreatic NENs [42] (Table 1). Similar difference was reported in the Gupta study where progression free survival as well as tumor response rate were higher in carcinoids than in
pNENs [21]. On the contrary, no difference in overall survival, progression free survival and objective response was reported by Ho et al. [48] (Table 1).

On the other hand, symptomatic response and duration of the response were similar for patients with carcinoid tumors and pancreatic NEN [21,35,42- 
Table 4 Indications and contraindications of TAE in patients with NENs

\begin{tabular}{ll}
\hline Indications & Contraindications \\
\hline - NEN tumor functioning & - Massive tumor burden \\
or not & \\
- Highly vascularised liver & - Severely compromised liver function \\
metastases & \\
- Liver metastases $>3$ in & - Poor performance status \\
number and or $>3 \mathrm{~cm}$ in size & - Sepsis \\
- Patients with tumor mass- & - Carcinoid heart disease and other risk \\
related symptoms and/or & factors for treatment related mortality \\
carcinoid syndrome & \\
\hline
\end{tabular}

$46,48,51,52]$ (Table 2). In general, the duration of response was longer in patients treated for hormonal symptoms with or without pain, while it was shorter when the indication was pain alone [45] (Table 2).

\section{Safety}

TAE was found to be a quite safe procedure. Range of TAE-related death was from 2 to 13 patients, with a total of 50 deaths. Adverse events such as ischemia of biliary tree, post-embolization syndrome may occur. Complications were observed in a total of 125 patients (14\%) of all 896 patients with NENs, but it is not always clarified wether adverse events and toxicity occurred after TAE and/or TACE (Table 3). Post-embolization syndrome includes abdominal pain, nausea, fevers, hypertension, thrombocytopenia, leukocytosis, transient increase in liver enzymes (predominantly transaminases) and LDH which generally comes down within a few days to 2-3 weeks. Increased bilirubin levels have also been noted. Ischemia of the biliary tree has also been rarely reported and moderate elevation of alkaline phosphatase. When some devices were considered to keep the patient well hydrated and in supportive care, post-embolization syndrome resulted to be less frequent $[4,44]$. As a whole, TAE may be considered a quite safe procedure, given the high number of procedures carried out (979) and the low number of deaths (50 patients: 6\%) and complications (125 patients: 14\%) (Table 3).

\section{Conclusions}

TAE appears to be an optimal treatment approach for inoperable liver metastases from NENs, for higher metastatic load, for management of symptoms alone and in association with interferon or somatostatin analogues, suggesting a prolonged 5-yr survival and local tumor control and for survival improvement [42,43,45,51]. Tumor response as well as survival, but not clinical and biochemical response, appear to be better for patients with carcinoid than pancreatic NENs.
TAE is considered a safe procedure. The low number of complications during and/or after TAE procedures can be easily and quickly treated, while the small number of deaths further confirms the safety of this technique. Moreover the deaths are often associated with adverse effects not related to TAE, but with the chemotherapeutic agents used for TACE. It is essential that TAE is performed by highly qualified and specialized team. Finally, the presence of extra-hepatic metastases or unresected primary tumor should not limit the use of TAE [48] since the liver function plays the most important role in the survival of these patients.

On the other hand, TAE should be avoided in patients with massive tumor burden and severely compromised liver function, poor performance status, sepsis, carcinoid heart disease and other risk factors for treatment related mortality (Table 4). In these cases less aggressive TAE, repeated if needed, can be effective, while decreasing the risk for procedure related mortality $[49,50]$.

Future randomized, prospective clinical trials comparing safety, efficacy and lorng term outcomes of different treatment approaches for liver metastases in NEN patients with comparable disease, should better define the role of TAE. In conclusion, available data suggest TAE as a safe therapeutic option in patiens with liver metastases from NENs, effective for controlling tumor progression and improving mass and endocrine symptoms, while increasing long term survival. In order to minimize risk related procedure TAE should be performed in a multidisciplinary setting and in experienced NEN centers. Finally, the choice of TAE instead of TACE, PRRT, chemotherapy or biotherapy should be performed in a multidisciplinary setting and in experienced NEN centers, according to patient and tumor characteristics.

\section{Abbreviations}

NENs: Neuroendocrine neoplasms; TAE: Trans-arterial embolization; TACE: Trans-arterial chemoembolization; CgA: Chromogranin A; 5HIAA: Urinary 5-hydroxyindoleacetic acid; CT: Computed tomography; PET: Positron emission tomography; MRI: Magnetic resonance imaging; Octreoscan: [111-In-diethylene-triamine-penta-acetic-acid (DTPA)-D-Phe1]octreotide; DOTA: Tricarboxy-methyl-1-yl-acetyl-D-Phe1; DOTATOC: Try3octreotide; DOTANOC: DOTA-1-Nal3-octreotide; PVA: Polyvinyl alcohol; PNEN: Neuroendocrine neoplasm of pancreas; TR: Tumor response; OS: Overall survival; PR: Partial response; CR: Complete response; MR: Minor response; SD: Stable disease; PD: Progressive disease; BR: Biochemical response; SR: Symptomatic response.

\section{Competing interest}

All the authors declare that there are no competing interest that could be perceived as prejudicing the impartiality of the data reported.

\section{Authors' contribution}

All the authors contributed to the preparation of this review. MDP and FF wrote the review, RM, VM, FM, VR, ADS, ST, FT and RB contributed to the research of articles of literature, ACC and CC LDR made the tables and finally $A C$ and $A F$ wrote and revised the review. All authors read and approved the final manuscript. 


\section{Acknowledgement}

We are extremely grateful to all subjects who took part in these studies and the research teams who collected the data.

\section{Role of funding source}

This review did not receive any specific grant from any funding agency in the public, commercial or not-for-profit sector.

\section{Author details}

'Divisione di Endocrinologia, Dipartimento di Medicina Clinica e Chirurgia, Università di Napoli Federico II, Naples, Italy. ${ }^{2}$ Divisione di Radiologia Interventistica, Dipartimento di Diagnostica per Immagini, Terapia Radiante e Metabolica, "Istituto Nazionale Tumori "Fondazione G. Pascale" - IRCCS, Naples, Italy. Interventional Unit Ultrasound A.O. Dei Colli, Naples, Italy. ${ }^{4}$ Divisione di Oncologia Medica Addominale, Dipartimento di Oncologia Addominale, "Istituto Nazionale Tumori "Fondazione G. Pascale" - IRCCS, Naples, Italy. ${ }^{5}$ Divisione di Anatomia Patologica e Citopatologia, Dipartimento di Patologia diagnostica e di Laboratorio, "Istituto Nazionale Tumori "Fondazione G. Pascale" - IRCCS, Naples, Italy. 'Divisione di Endocrinologia, Istituto Nazionale Tumori, Regina Elena, Rome, Italy.

Received: 6 March 2014 Accepted: 5 May 2014

Published: 19 May 2014

\section{References}

1. Bosman FT: World Health Organization, and International Agency for Research on Cancer. In WHO classification of tumours of the digestive system, World Health Organization classification of tumours. 4th edition. Lyon: International Agency for Research on Cancer; 2010:417.

2. Yao JC, Hassan M, Phan A, Dagohoy C, Leary C, Mares JE, Abdalla EK Fleming JB, Vauthey JN, Rashid A, Evans DB: One hundred years after "carcinoid": epidemiology of and prognostic factors for neuroendocrine tumors in 35,825 cases in the United States. $J$ Clin Oncol 2008, 26(18):3063-3072.

3. Fraenkel M, Kim M, Faggiano A, de Herder WW, Valk GD, Knowledge NETwork: Incidence of gastroenteropancreatic neuroendocrine tumours: a systematic review of the literature. Endocr Relat Canc 2013, 21(3):R153-R163.

4. Touzios JG, Kiely JM, Pitt SC, Rilling WS, Quebbeman EJ, Wilson SD, Pitt HA: Neuroendocrine hepatic metastases: does aggressive management improve survival?. Ann Surg 2005, 241(5):776-783. discussion 783-5.

5. Hemminki K, Li X: Incidence trends and risk factors of carcinoid tumors: a nationwide epidemiologic study from Sweden. Cancer 2001, 92(8):2204-2210

6. Modlin IM, Lye KD, Kidd M: A 5-decade analysis of 13,715 carcinoid tumors. Cancer 2003, 97(4):934-959.

7. Oberg K, Eriksson B: Endocrine tumours of the pancreas. Best Pract Res Clin Gastroenterol 2005, 19(5):753-781.

8. Norheim I, Oberg K, Theodorsson-Norheim E, Lindgren PG, Lundqvist G, Magnusson A, Wide L, Wilander E: Malignant carcinoid tumors. An analysis of 103 patients with regard to tumor localization, hormone production, and survival. Ann Surg 1987, 206(2):115-125.

9. Loewe C, Schindl M, Cejna M, Niederle B, Lammer J, Thurnher S: Permanent transarterial embolization of neuroendocrine metastases of the liver using cyanoacrylate and lipiodol: assessment of mid- and long-term results. AJR Am J Roentgenol 2003, 180(5):1379-1384.

10. Pavel M, Baudin E, Couvelard A, Krenning E, Öberg K, Steinmüller T, Anlauf M, Wiedenmann B, Salazar R, Barcelona Consensus Conference participants: ENETS Consensus Guidelines for the management of patients with liver and other distant metastases from neuroendocrine neoplasms of foregut, midgut, hindgut, and unknown primary. Neuroendocrinology 2012, 95(2):157-176.

11. Blonski WC, Reddy KR, Shaked A, Siegelman E, Metz DC: Liver transplantation for metastatic neuroendocrine tumor: a case report and review of the literature. World J Gastroenterol 2005, 11(48):7676-7683.

12. Oberg K, Norheim I, Lundqvist G, Wide L: Cytotoxic treatment in patients with malignant carcinoid tumors. Response to streptozocin-alone or in combination with 5-FU. Acta Oncol 1987, 26(6):429-432.

13. Oberg K: Chemotherapy and biotherapy in the treatment of neuroendocrine tumours. Ann Oncol 2001, 12(Suppl 2):S111-S114.
14. Arnold R, Trautmann ME, Creutzfeldt W, Benning R, Benning M, Neuhaus C, Jürgensen R, Stein K, Schäfer H, Bruns C, Dennler HJ: Somatostatin analogue octreotide and inhibition of tumour growth in metastatic endocrine gastroenteropancreatic tumours. Gut 1996, 38(3):430-438.

15. Strosberg JR, Nasir A, Hodul P, Kvols L: Biology and treatment of metastatic gastrointestinal neuroendocrine tumors. Gastrointest Canc Res 2008, 2(3):113-125

16. Kulke $\mathrm{MH}$ : Gastrointestinal neuroendocrine tumors: a role for targeted therapies? Endocr Relat Canc 2007, 14(2):207-219.

17. Raymond E, Dahan L, Raoul JL, Bang YJ, Borbath I, Lombard-Bohas C, Valle J, Metrakos P, Smith D, Vinik A, Chen JS, Hörsch D, Hammel P, Wiedenmann B, Van Cutsem E, Patyna S, Lu DR, Blanckmeister C, Chao R, Ruszniewski P: Sunitinib malate for the treatment of pancreatic neuroendocrine tumors. N Engl J Med 2011, 364(6):501-513.

18. Allison DJ, Modlin IM, Jenkins WJ: Treatment of carcinoid liver metastases by hepatic-artery embolisation. Lancet 1977, 2(8052-8053):1323-1325.

19. Ajani JA, Carrasco CH, Charnsangavej C, Samaan NA, Levin B, Wallace S: Islet cell tumors metastatic to the liver: effective palliation by sequential hepatic artery embolization. Ann Intern Med 1988, 108(3):340-344.

20. Madoff DC, Gupta S, Ahrar K, Murthy R, Yao JC: Update on the management of neuroendocrine hepatic metastases. J Vasc Interv Radiol 2006, 17(8):1235-1249. quiz 1250.

21. Gupta S, Yao JC, Ahrar K, Wallace MJ, Morello FA, Madoff DC, Murthy R, Hicks ME, Ajani JA: Hepatic artery embolization and chemoembolization for treatment of patients with metastatic carcinoid tumors: the M.D. Anderson experience. Cancer J 2003, 9(4):261-267.

22. Pelage JP, Soyer P, Boudiaf M, Brocheriou-Spelle I, Dufresne AC, Coumbaras J, Rymer R: Carcinoid tumors of the abdomen: CT features. Abdom Imaging 1999, 24(3):240-245.

23. Marotta V, Nuzzo V, Ferrara T, Zuccoli A, Masone M, Nocerino L, Del Prete M, Marciello F, Ramundo V, Lombardi G, Vitale M, Colao A, Faggiano A: Limitations of Chromogranin A in clinical practice. Biomarkers 2012, 17(2):186-191.

24. Oberg K, Stridsberg M: Chromogranins as diagnostic and prognostic markers in neuroendocrine tumours. Adv Exp Med Biol 2000, 482:329-337.

25. Carling RS, Degg TJ, Allen KR, Bax ND, Barth JH: Evaluation of whole blood serotonin and plasma and urine 5-hydroxyindole acetic acid in diagnosis of carcinoid disease. Ann Clin Biochem 2002, 39(Pt 6):577-582.

26. Lamberts SW, Hofland $\amalg$, Nobels FR: Neuroendocrine tumor markers. Front Neuroendocrinol 2001, 22(4):309-339.

27. Ferolla P, Faggiano A, Mansueto G, Avenia N, Cantelmi MG, Giovenali P, Del Basso De Caro ML, Milone F, Scarpelli G, Masone S, Santeusanio F, Lombardi $G$, Angeletti G, Colao A: The biological characterization of neuroendocrine tumors: the role of neuroendocrine markers. J Endocrinol Invest 2008, 31(3):277-286.

28. Panzuto F, Falconi M, Nasoni S, Angeletti S, Moretti A, Bezzi M, Gualdi G, Polettini E, Sciuto R, Festa A, Scopinaro F, Corleto VD, Bordi C, Pederzoli P, Delle Fave G: Staging of digestive endocrine tumours using helical computed tomography and somatostatin receptor scintigraphy. Ann Oncol 2003, 14(4):586-591.

29. Seemann MD: Detection of metastases from gastrointestinal neuroendocrine tumors: prospective comparison of 18 F-TOCA PET, triple-phase CT, and PET/CT. Technol Canc Res Treat 2007, 6(3):213-220.

30. Dromain C, de Baere T, Lumbroso J, Caillet H, Laplanche A, Boige V, Ducreux M, Duvillard P, Elias D, Schlumberger M, Sigal R, Baudin E: Detection of liver metastases from endocrine tumors: a prospective comparison of somatostatin receptor scintigraphy, computed tomography, and magnetic resonance imaging. J Clin Oncol 2005, 23(1):70-78

31. Reubi JC, Schär JC, Waser B, Wenger S, Heppeler A, Schmitt JS, Mäcke HR: Affinity profiles for human somatostatin receptor subtypes SST1-SST5 of somatostatin radiotracers selected for scintigraphic and radiotherapeutic use. Eur J Nucl Med 2000, 27(3):273-282.

32. Al-Nahhas A, Win Z, Szyszko T, Singh A, Nanni C, Fanti S, Rubello D: Gallium-68 PET: a new frontier in receptor cancer imaging. Anticancer Res 2007, 27(6B):4087-4094.

33. Lopci E, Nanni C, Rampin L, Rubello D, Fanti S: Clinical applications of 68Ga-DOTANOC in neuroendocrine tumours. Minerva Endocrinol 2008, 33(3):277-281.

34. Nicholson SA, Ryan MR: A review of cytologic findings in neuroendocrine carcinomas including carcinoid tumors with histologic correlation. Cancer 2000, 90(3):148-161. 
35. Carrasco CH, Charnsangavej C, Ajani J, Samaan NA, Richli W, Wallace S: The carcinoid syndrome: palliation by hepatic artery embolization. AJR Am J Roentgenol 1986, 147(1):149-154.

36. Venook AP: Embolization and chemoembolization therapy for neuroendocrine tumors. Curr Opin Oncol 1999, 11(1):38-41.

37. Strosberg JR, Cheema A, Kvols LK: A review of systemic and liver-directed therapies for metastatic neuroendocrine tumors of the gastroenteropancreatic tract. Cancer Control 2011, 18(2):127-137.

38. Yao KA, Talamonti MS, Nemcek A, Angelos P, Chrisman H, Skarda J, Benson $A B$, Rao $S$, Joehl RJ: Indications and results of liver resection and hepatic chemoembolization for metastatic gastrointestinal neuroendocrine tumors. Surgery 2001, 130(4):677-682. discussion 682-5.

39. Strosberg JR, Choi J, Cantor AB, Kvols LK: Selective hepatic artery embolization for treatment of patients with metastatic carcinoid and pancreatic endocrine tumors. Cancer Control 2006, 13(1):72-78.

40. Gupta S, Johnson MM, Murthy R, Ahrar K, Wallace MJ, Madoff DC, McRae SE, Hicks ME, Rao S, Vauthey JN, Ajani JA, Yao JC: Hepatic arterial embolization and chemoembolization for the treatment of patients with metastatic neuroendocrine tumors: variables affecting response rates and survival. Cancer 2005, 104(8):1590-1602.

41. Schell SR, Camp ER, Caridi JG, Hawkins IF Jr: Hepatic artery embolization for control of symptoms, octreotide requirements, and tumor progression in metastatic carcinoid tumors. J Gastrointest Surg 2002, 6(5):664-670.

42. Hanssen LE, Schrumpf E, Kolbenstvedt AN, Tausjø J, Dolva LO: Treatment of malignant metastatic midgut carcinoid tumours with recombinant human alpha2b interferon with or without prior hepatic artery embolization. Scand J Gastroenterol 1989, 24(7):787-795.

43. Wangberg B, Westberg G, Tylén U, Tisell L, Jansson S, Nilsson O, Johansson $\mathrm{V}$, Scherstén T, Ahlman $\mathrm{H}$ : Survival of patients with disseminated midgut carcinoid tumors after aggressive tumor reduction. World J Surg 1996, 20(7):892-899. discussion 899.

44. Eriksson BK, Larsson EG, Skogseid BM, Löfberg AM, Lörelius LE, Oberg KE: Liver embolizations of patients with malignant neuroendocrine gastrointestinal tumors. Cancer 1998, 83(11):2293-2301.

45. Brown KT, Koh BY, Brody LA, Getrajdman Gl, Susman J, Fong Y, Blumgart LH: Particle embolization of hepatic neuroendocrine metastases for control of pain and hormonal symptoms. J Vasc Interv Radiol 1999, 10(4):397-403.

46. Chamberlain RS, Canes D, Brown KT, Saltz L, Jarnagin W, Fong Y, Blumgart $\mathrm{LH}$ : Hepatic neuroendocrine metastases: does intervention alter outcomes?. J Am Coll Surg 2000, 190(4):432-445.

47. Ruutiainen AT, Soulen MC, Tuite CM, Clark TW, Mondschein Jl, Stavropoulos SW, Trerotola SO: Chemoembolization and bland embolization of neuroendocrine tumor metastases to the liver. J Vasc Interv Radiol 2007, 18(7):847-855.

48. Ho AS, Picus J, Darcy MD, Tan B, Gould JE, Pilgram TK, Brown DB: Longterm outcome after chemoembolization and embolization of hepatic metastatic lesions from neuroendocrine tumors. AJR Am J Roentgenol 2007, 188(5):1201-1207.

49. Kamat PP, Gupta S, Ensor JE, Murthy R, Ahrar K, Madoff DC, Wallace MJ, Hicks ME: Hepatic arterial embolization and chemoembolization in the management of patients with large-volume liver metastases. Cardiovasc Intervent Radiol 2008, 31(2):299-307.

50. Pitt SC, Knuth J, Keily JM, McDermott JC, Weber SM, Chen H, Rilling WS, Quebbeman EJ, Agarwal DM, Pitt HA: Hepatic neuroendocrine metastases: chemo- or bland embolization? J Gastrointest Surg 2008, 12(11):1951-1960.

51. Sward C, Johanson V, Nieveen van Dijkum E, Jansson S, Nilsson O, Wängberg B, Ahlman $H$, Kölby L: Prolonged survival after hepatic artery embolization in patients with midgut carcinoid syndrome. Br J Surg 2009, 96(5):517-521.

52. Fiore F, Del Prete M, Franco R, Marotta $V$, Ramundo V, Marciello F, Di Sarno A, Carratù AC, de Luca di Roseto C, Colao A, Faggiano A: Transarterial embolization (TAE) is equally effective and slightly safer than transarterial chemoembolization (TACE) to manage liver metastases in neuroendocrine tumors. Endocrine 2014, [Epub ahead of print].

53. Perez EA, Koniaris LG, Snell SE, Gutierrez JC, Sumner WE 3rd, Lee DJ, Hodgson NC, Livingstone AS, Franceschi D: 7201 carcinoids: increasing incidence overall and disproportionate mortality in the elderly. World J Surg 2007, 31(5):1022-1030.

54. Dominguez S, Denys A, Madeira I, Hammel P, Vilgrain V, Menu Y, Bernades P, Ruszniewski P: Hepatic arterial chemoembolization with streptozotocin in patients with metastatic digestive endocrine tumours. Eur J Gastroenterol Hepatol 2000, 12(2):151-157.
55. Casadei R, Tomassetti P, Rossi C, la Donna M, Migliori M, Marrano D: Treatment of metastatic glucagonoma to the liver: case report and literature review. Ital J Gastroenterol Hepatol 1999, 31(4):308-312.

56. Lee $\mathrm{SM}$, Forbes A, Williams R: Metastatic islet cell tumour with clinical manifestations of insulin and glucagon excess: successful treatment by hepatic artery embolization and chemotherapy. Eur J Surg Oncol 1988, 14(3):265-268.

57. Ruszniewski $P$, Rougier $P$, Roche A, Legmann $P$, Sibert A, Hochlaf $S$, Ychou M, Mignon M: Hepatic arterial chemoembolization in patients with liver metastases of endocrine tumors. A prospective phase II study in 24 patients. Cancer 1993, 71(8):2624-2630.

\section{doi:10.1186/1756-9966-33-43}

Cite this article as: Del Prete et al:: Hepatic arterial embolization in patients with neuroendocrine tumors. Journal of Experimental \& Clinical Cancer Research 2014 33:43.

\section{Submit your next manuscript to BioMed Central and take full advantage of:}

- Convenient online submission

- Thorough peer review

- No space constraints or color figure charges

- Immediate publication on acceptance

- Inclusion in PubMed, CAS, Scopus and Google Scholar

- Research which is freely available for redistribution 